\title{
Review: \\ Potensi Limbah Plastik Dan Biomassa Sebagai Sumber Energi Terbarukan Dengan Proses Pirolisis
}

\author{
Herliati $^{1)}$, Septian Bagus Prasetyo ${ }^{2)}$ dan Yogi Verinaldy ${ }^{3)}$ \\ Fakultas Teknologi Industri Universitas Jayabaya \\ Jl. Raya Bogor Km. 28,8 Cimanggis, Jakarta Timur / Telp. (021) 8714823, 8722485. \\ Corresponding author :herliati@ftijayabaya.ac.id
}

\begin{abstract}
Plastic waste with various types such as Polyethylene Tereptalat (PET), high-density polyethylene (HDPE), Low Density polyethylene (LDPE), and polypropylene (PP) is the problem that must be solved which Indonesia is the second largest country in the world as a producer of plastics waste. In addition Indonesia also has a huge local potential in generating the waste biomass of organic compounds such as sewage farms and plantations. It is otherwise resolved of course would be bad for the environment. Several alternatives have been performed in order to manage such waste through recycling technology. However this method has its disadvantages because it takes paying high costs for labor and separation process as well as contamination in bodies of water so that the method is difficult to apply as sustainable. Therefore, the researchers then turned their attention on the utilization of the above wastes as an alternative energy source that is liquid fuel. This paper is an review of the potential conversion of plastics waste and organic waste into liquid fuel by pyrolysis technology. The main parameters examined i.e. temperature, pressure, reactor, residence time and catalyst. In addition, the idea for the optimization of fuel products are also discussed here.
\end{abstract}

\begin{abstract}
Abstrak
Limbah plastik dengan berbagai jenis seperti Polietilen Tereptalat (PET), High-Density polietilen (HDPE), Low-Density polietilen (LDPE), dan polipropilen (PP) merupakan masalah yang harus diatasi dimana Indonesia merupakan negara penyumbang terbesar kedua di dunia. Selain itu Indonesia juga memiliki potensi lokal yang besar dalam menghasilkan limbah biomassa yang merupakan senyawa organik seperti limbah pertanian dan perkebunan. Hal ini kalau tidak diatasi tentu saja akan berdampak buruk bagi lingkungan. Beberapa alternatif telah dilakukan dalam rangka mengelola limbah tersebut melalui teknologi daur ulang. Namun metode ini memiliki kelemahan karena dibutuhkan biaya yang tinggi untuk membayar tenaga kerja dan biaya proses pemisahan serta mengakibatkan kontaminasi pada air sungai sehingga metode ini sulit untuk diterapkan secara berkelanjutan. Oleh karena itu, para peneliti kemudian beralih perhatiannya pada pemanfaatan limbah plastik dan biomassa sebagai sumber energi alternatif yaitu bahan bakar cair. Tulisan ini merupakan telaah potensi konversi limbah plastik dan limbah organik menjadi bahan bakar cair dengan teknologi pirolisis. Parameter utama yang dikaji yaitu suhu, tekanan, jenis reaktor, waktu tinggal dan katalis. Selain itu, gagasan untuk optimasi produk bahan bakar juga dibahas di sini.
\end{abstract}

Keywords: Biomass, Fossil Fuels, Liquid Fuels, Plastics Waste, Pyrolysis 
Jurnal Teknologi, Tahun 2019, Volume 6, Edisi 2

\section{Pendahuluan}

Dalam dasawarsa ini masalah persoalan berkurangnya ketersediaan Bahan Bakar yang bersumber dari fosil di dunia telah menjadi perbincangan umum karena cadangan bahan bakar fosil terus menurun [1]. Laporan dunia tahun 2010 bahwa konsumsi petroleum terus meningkat dengan pertumbuhan 1 persen per tahun, sementara konsumsi gas alam juga meningkat dengan pertumbuhan 1,5 persen per tahun [2]. Dapat dibayangkan, jika minyak dan gas tidak dapat dihemat penggunaannya maka gas dan minyak dunia hanya akan tersedia 43 dan 167 tahun yang akan datang. Karena itu sumber alternatif energi terbarukan seperti biomassa, hydropower, geothermal, energi angin, nuklir, dan lain sebagainya menjadi hal yang menarik untuk dikaji. Sampah plastik merupakan salah satu alternatif, sebagai feedstock bahan bakar cair, yang mana dapat berkontribusi sebagai pengganti petroleum [3]. Indonesia sebagai negara dengan jumlah penduduk terbesar ke-lima tentu saja mengalami masalah yang sama [4]. Cadangan bahan bakar minyak di Indonesia yang semakin berkurang sementara laju konsumsi semakin meningkat mengakibatkan pemerintah harus menerapkan kebijakan guna mencari alternatif bahan bakar pengganti BBM [5,6]. Pemerintah telah melakukan berbagai upaya penghematan energi sambal secara masif mendorong berkembangnya sumber energi baru dan terbarukan. Salah satu bahan bakar alternatif yang ramai dibicarakan adalah bahan bakar dari sampah plastik dan biomassa $[5,7,8]$.

Sampah plastik merupakan limbah yang sangat sulit terurai kecuali dalam waktu yang sangat lama [2]. Selain itu sampah plastik memberikan dampak buruk pada kehidupan manusia antara lain kesehatan, lingkungan, dan sosial ekonomi [9]. Indonesia negara terbesar kedua penyumbang sampah plastik dunia dengan menyumbang sekitar 1,29 juta metrik ton $[10,11]$. Jenis Sampah plastik yang banyak dijumpai terutama di wilayah perkotaan yaitu PET, HDPE, PVC, LDPE, dan PP [12]. Semakin tinggi kebutuhan akan penggunaan plastik untuk berbagai keperluan termasuk untuk kegunaan rumah tangga akan berdampak pada tingginya laju penumpukan sampah plastik $[13,14]$. Secara kimiawi plastik adalah polimer yang terdiri dari monomer rantai panjang. Untungnya melalui proses pirolisis polimer tersebut dapat direngkah dan dikonversi menjadi bahan bakar cair seperti kerosen, disel dan bensin $[15,16]$.

Untuk mengurangi sampah plastik yang dibuang ke TPA, awalnya metode daur ulang dianggap sebagai alternatif untuk mengelola sampah plastik. Namun terbukti bahwa proses daur ulang plastik sangat sulit dan mahal karena terkendala biaya buruh untuk proses pemisahan [17]. Selain itu, proses daur ulang memiliki potensi terhadap pencemaran air sungai [18]. Pemisahan diperlukan karena plastik terbuat dari berbagai jenis dengan kegunaan yang berbeda. Salah satu teknologi alternatif konversi sampah plastik atau biomassa menjadi bahan bakar cair adalah proses pirolisis yaitu sebuah reaksi perengkahan termal tanpa menggunakan oksigen. Saat ini, pirolisis telah menjadi perhatian serius sebagai salah satu metode konversi sampah plastik menjadi bahan bakar cair karena memberikan manfaat baik secara ekonomi maupun kaitannya dengan pencegahan pencemaran lingkungan [19].

Selain sampah plastik, biomassa juga dapat dimanfaatkan sebagai sumber alternatif bahan baku untuk mengatasi persoalan saat ini dimana cadangan energi dunia mengalami kecenderungan menurun [20]. Biomassa memiliki ketersediaan melimpah di Indonesia bahkan di seluruh dunia [5, 6, 21]. Khusus di Indonesia, potensi limbah pertanian, kehutanan dan sampah padat perkotaan sebagai sumber energi diperkirakan mencapai 200 ton/tahun [22]. Pemanfaatan biomassa sebagai bahan bakar mendapat perhatian yang besar dari para peneliti karena pertimbangan ramah lingkungan yaitu kandungan belerang dan nitrogen yang rendah dibandingkan dengan bahan bakar fosil, hal ini sangat terkait dengan gas emisi berbahaya seperti gas nitrous $\left(\mathrm{NO}_{\mathrm{x}}\right)$ dan sulfur dioksida $\left(\mathrm{SO}_{2}\right)$ [23]. 
Konversi biomassa menjadi biofuel melalui proses fermentasi telah dilakukan oleh para peneliti, namun metode ini kurang berkembang karena memiliki kelemahan dalam hal waktu reaksi yang lama. Oleh karena itu dibutuhkan metode alternatif yang lebih efisien. Produksi biofuel (minyak, gas dan char) dengan proses pirolisis menggunakan berbagai jenis biomassa telah diselidiki secara ekstensif oleh banyak peneliti. Para peneliti lebih tertarik mengembangkan metode pirolisis untuk mengkonversi biomassa menjadi bahan bakar cair karena memiliki keuntungan dalam hal penyimpanan, transportasi dan fleksibilitas dalam aplikasinya [24]. Beberapa jenis biomassa tersebut diantaranya kayu, tandan kosong kelapa sawit, sampah organik rumah tangga, dll [5]. Teknologi pirolisis memiliki kemampuan untuk memproduksi bahan bakar cair dari biomassa dengan yield bahan bakar yang tinggi [20].

Tujuan dari review ini adalah untuk mengkaji parameter-parameter penting dalam proses pirolisis seperti suhu, tekanan, jenis reaktor, waktu tinggal dan katalis serta memberikan gambaran kondisi terbaik dari parameter-parameter yang disebutkan

\section{Metodologi}

Metode yang digunakan pada studi ini berupa kajian literatur yang luas dan mendalam terhadap parameter-parameter suhu, tekanan, jenis reaktor, waktu tinggal dan katalis. pada topik pirolisis baik untuk sampah plastik maupun biomassa. Sumber kajian ini adalah data sekunder yang digunakan termasuk internet, laporan penelitian, prosiding, dan artikel jurnal nasional maupun internasional yang fokus pada konversi plastik dan biomassa menjadi bahan bakar cair menggunakan teknologi pirolisis.

\section{Plastik}

\subsection{Polyethylene terephthalate (PET)}

PET adalah jenis plastik yang digunakan secara luas sebagai kemasan berbagai produk makanan dan minuman seperti air mineral, botol minuman ringan dan wadah jus buah. Hal ini adalah karena sifat dasar PET yang keras dan kuat, ringan dan tahan terhadap tekanan, sangat cocok untuk digunakan sebagai kemasan termasuk juga jika digunakan untuk kemasan dengan kapasitas yang besar [25]. Selain itu, PET juga digunakan sebagai isolasi listrik, pita magnetik, Xray dan film fotografi lainnya [26]. Penggunaan PET yang sangat besar ini, dimana meningkat $12 \%$ per tahun, akan menyebabkan tumpukan PET di tempat pembuangan sampah semakin besar [27]. Daur ulang limbah PET tidak ekonomis karena membutukan biaya pemisahan yang tinggi. Oleh karena itu, alternatif lain pemanfaatan limbah PET dengan cara mengkonversinya menjadi bahan bakar cair menggunakan teknologi pirolisis telah dieksplorasi oleh beberapa peneliti $[13,15,28]$.

Potensi konversi PET untuk menghasilkan minyak cair menggunakan reactor fixedBed dengan proses pirolisis pada suhu $500^{\circ} \mathrm{C}$ telah dilakukan $[29,30]$. Dilaporkan bahwa dengan metode ini diperoleh bahan bakar cair 30 - $40 \%$ berat sementara bahan bakar gas 60 $80 \%$ berat dan padatan residu $10-20 \%$ berat $[31,32,33$. Namun dari hasil karakterisasi produk, hasil pirolisis menunjukkan tingkat keasaman yang tinggi disebabkan kandungan asam benzoat. Hal ini tentu tidak menguntungkan karena selain dapat menyumbat pipa dan heat exchanger jga dapat menimbulkan korosif pada pemakaiannya, sehingga membutuhkan perhatian serius jika diterapkan untuk skala industri [32].

\subsection{High-density polyethylene (HDPE)}

HDPE adalah sebuah polimer senyawa hidrokarbon panjang rantai lurus yang memiliki kekerasan tinggi serta tidak mudah terdegradasi oleh paparan matahari, perubahan cuaca (panas atau dingin). Berdasarkan sifat-sifat ini, HDPE banyak digunakan untuk kemasan botol susu, wadah detergen, botol minyak, mainan anak dan lain sebagainya $[33,34]$. Jenis 
plastik ini menghasilkan limbah 18-30\% volume dari total limbah padat rumah tangga. Untuk itu persoalan ini merupakan hal yang sangat serius untuk diatasi. Dari beberapa hasil penelitian melaporkan bahwa limbah HDPE dapat dirubah menjadi bahan bakar menggunakan proses pirolisis $[3,9,13,35]$. Dapat disimpulkan bahwa kondisi suhu yang digunakan berkisar antara $300-400{ }^{\circ} \mathrm{C}$ di dalam reaktor fluidized-Bed. Hasil penelitian memperoleh bahan bakar cair $60-70 \%$ berat sementara bahan bakar gas 20 - $30 \%$ berat dan padatan residu sampai $10 \%$ berat $[33,34,36]$.

\subsection{Low-density polyethylene (LDPE)}

Berbeda dengan HDPE, LDPE adalah jenis polimer yang memiliki banyak cabang sehingga memiliki gaya intermokelul yang lebih lemah tentu saja konsekuansinya memiliki kekuatan tekan dan kekerasan yang lebih rendah dibandingkan HDPE [12]. Namun demikian, LDPE memiliki keunggulan dalam hal mudah dibentuk dan resisten terhadap air. Untuk itu LDPE banyak digunakan untuk kantong plastik, pembungkus foil untuk Kemasan, kantong sampah dan lain sebagainya. Sebagai konsekuensi LDPE banyak dijumpai di tempat pembuangan akhir sampah dimana menempati urutan kedua sebagai penyumbang sampah padatan setelah polipropilen $[33,34]$. Sebagai salah satu cara untuk mengatasi persoalan limbah ini adalah dengan mengkonversi LDPE menjadi energi. Teknologi pirolisis, untuk merubah limbah LDPE menjadi bahan bakar, telah menjadi perhatian oleh banyak peneliti saat ini $[18,19,37]$.

Berbeda dengan pirolisis HDPE, reaktor fluidized-bed pada kisaran suhu $400-500{ }^{\circ} \mathrm{C}$ dengan laju pemanasan $10{ }^{\circ} \mathrm{C} /$ menit digunakan pada pirolisis LDPE. Pengamatan berlangsung selama 20 menit dimana gas nitrogen berfungsi sebagai agen fluidisasi. Dengan bahan LDPE, bahan bakar cair yang dihasilkan lebih tinggi yaitu antara $70-90 \%$ berat, gas yang dihasilkan sedikit dan tidak ada sama sekali padatan yang tersisa $[12,38,39]$.

\subsection{Polypropylene (PP)}

PP adalah polimer jenuh dengan rantai hidrokarbon lurus memiliki sifat tahan terhadap panas yang baik. Tidak seperti HDPE, PP tidak mencair pada suhu di bawah $160{ }^{\circ} \mathrm{C}$. PP memiliki densitas lebih rendah dibandingkan HDPE tetapi memiliki kekerasan tinggi dan kekakuan yang lebih sehingga PP lebih disukai sebagai plastik industri [40]. PP memberikan kontribusi limbah plastik sekitar 24\% dimana merupakan limbah plastik terbesar yang terdapat di tempat pembuangan akhir [41]. Aplikasi PP sangat beragam termasuk pot bunga, folder arsip, ember, karpet, mebel, kotak penyimpanan dan lain sebagainya [40]. Tingginya pemakaian PP dalam kehidupan sehari-hari menyebabkan jumlah limbah PP limbah akan meningkat setiap tahun dan oleh karena itu, proses pirolisis merupakan metode alternatif yang telah dipelajari untuk mengkonversi limbah plastik menjadi energi terbarukan sekaligus mengatasi masalah penumpukan limbah. Beberapa peneliti telah melakukan evaluasi terhadap metode pirolisis PP menggunaan berbagai parameter guna mengetahui sifat dan mengukur bahan bakar cair yang dihasilkan [12, 15, 19, 42].

Pirolisis PP dilakukan pada kondisi suhu berkisar antara $250-350{ }^{\circ} \mathrm{C}$ di dalam sebuah dilaporkan bahwa hasil terbaik diperoleh pada suhu sekitar $300{ }^{\circ} \mathrm{C}$ dimana konversi plastik hampir $99 \%$ dengan solid residu sebesar 1,5\% [12]. Ketika suhu mendekati $400{ }^{\circ} \mathrm{C}$ hasil yang diperoleh menjadi turun dimana terjadi kenaikan solid residu menjadi $5 \%$ berat. Hal ini memperlihatkan bahwa pembentukan coke terjadi pada suhu tinggi [33]. Fakta ini telah dikonfirmasi oleh peneliti lainnya dimana pirolisis pada suhu $>400{ }^{\circ} \mathrm{C}$ dijumpai hasil berupa liquid $80 \%$ berat, gas $6,6 \%$ berat dan padatan $13,3 \%$ berat. Kondisi suhu yang ekstrim yaitu 
$750{ }^{\circ} \mathrm{C}$ di dalam reaktor batch menghasilkan liquid $48,8 \%$ berat liquid, gas $49,6 \%$ berat dan $1,6 \%$ berat padatan [15].

\section{Biomassa}

Biomassa dapat didefinisikan sebagai bahan yang berasal dari tumbuh tumbuhan atau dari kotoran hewan yang utamanya terdiri dari karbon, hidrogen, oksigen, nitrogen dan sedikit kandungan anorganik [43]. Sumber energi biomassa adalah salah satu yang paling awal dan saat ini adalah terbesar ketiga di dunia, dimana 40-50\% dari total penggunaan energi di banyak negara berkembang yang memiliki wilayah hutan dan pertanian luas [5, 20]. Biomassa digunakan untuk memenuhi berbagai pasokan energi, termasuk pembangkit listrik, penghangat rumah dan untuk kebutuhan energi industri [44]. Biomassa yang akan dibahas dalam tulisan ini adalah bahan organik yang dapat dihasilkan dari sampah organik, dimana komposisi utama sampah kota adalah $65 \%$ berisi sampah organik [6]. atau berupa buangan kayu. Beberapa hasil penelitian melakukan analisis ultimate untuk kayu adalah sebagai berikut karbon $50-52 \%$, hidrogen 39 - 41\%, oksigen 6,35\%, dan nitrogen 0,4\% [5, 45].

Teknologi pirolisis, untuk merubah biomassa menjadi bahan bakar, telah menjadi perhatian para peneliti saat ini. Komponen utama dari biomassa yang berasal dari tumbuhtumbuhan adalah selulosa, hemiselulosa dan lignin, yang masing-masing berbeda dalam tingkat dekomposisi [46, 47]. Selain itu, dekomposisi dari setiap komponen yang disebutkan di atas tergantung pada suhu reaksi dan jenis reaktor yang digunakan. Dalam proses pirolisis, hemiselulosa adalah yang paling mudah terdekomposisi, selanjutnya selulosa, sementara lignin adalah yang paling sulit [20]. Menariknya, lignin maupun hemiselulosa dapat mempengaruhi karakteristik pirolisis selulosa sementara mereka tidak bisa mempengaruhi satu sama lain. Dilaporkan bahwa pada proses pirolisis yang berlangsung pada suhu 400$550^{\circ} \mathrm{C}$ telah dihasilkan minyak yang merupakan hasil dekomposisi selulosa, sementara padatan (bio-char) yang dihasilkan berasal dari lignin [48]. Oleh karena karakteristik physiokimia yang berbeda dari selulosa, hemiselulosa dan lignin, pirolisis biomassa dengan komposisi lignin yang tinggi dapat menghasilkan minyak lebih baik. Komposisi biomassa dari berbagai sumber yang berbeda ditampilkan dalam Tabel 1.

Tabel 1. Kandungan Selulosa, Hemiselulosa, dan Lignin Beberapa Biomassa

\begin{tabular}{lcccc}
\hline \multirow{2}{*}{ Sumber Biomassa } & \multicolumn{3}{c}{$\%$ berat } & \multirow{2}{*}{ Referensi } \\
\cline { 2 - 4 } & Selulosa & Hemiselulosa & Lignin & {$[20]$} \\
Kayu & $35-50$ & $20-30$ & $25-30$ & {$[46]$} \\
& $42-50$ & $25-38$ & $20-30$ & {$[49]$} \\
Jerami & $40-50$ & $24-40$ & $18-35$ & {$[20]$} \\
& $33-40$ & $20-25$ & $15-20$ & {$[46]$} \\
Ampas Tebu & 40 & 45 & 15 & {$[49]$} \\
Tongkol Jagung & 30 & 50 & 15 & {$[20]$} \\
& $19-24$ & $32-48$ & $23-32$ & {$[20]$} \\
Kertas bekas & 50.5 & 31 & 15 & {$[49]$} \\
& 45 & 35 & 15 & {$[49]$} \\
Daun & $60-70$ & $10-20$ & $5-10$ & {$[20]$} \\
& $80-85$ & $5-15$ & - & {$[49]$} \\
Kulit Pisang & $15-20$ & $80-85$ & - & {$[20]$} \\
& $15-20$ & $80-85$ & - & {$[49]$} \\
\hline
\end{tabular}




\section{Teori Pirolisis}

Pirolisis adalah proses degradasi termal tanpa adanya oksigen hal ini dalam rangka untuk mencegah pembentukan $\mathrm{CO}_{\mathrm{x}}, \mathrm{NO}_{\mathrm{x}}, \mathrm{SO}_{\mathrm{x}}$. Pada proses ini terjadi perengkahan hidrokarbon rantai panjang (polimer) menjadi monomer yang lebih kecil [35, 50]. Faktor-faktor utama yang mempengaruhi proses pirolisis yang akan dibahas dalam tulisan ini meliputi suhu perengkahan, jenis reaktor, dan waktu tinggal $[12,42,51]$.

\subsection{Temperatur}

Temperatur merupakan variable operasi yang memegang peranan paling penting dalam menentukan hasil produk pirolisis [37, 48]. Selain itu, temperatur juga memegang peranan penting dalam mengatur berhasil atau tidaknya reaksi cracking pada polimer plastik $[36,52]$ atau pada senyawa selulosa dalam biomassa [53]. Tidak semua bahan polimer dapat pecah dengan kenaikan temperatur. Gaya Van der Waals adalah gaya antara molekul-molekul, akan menarik molekul menjadi satu ikatan sehingga sulit untuk terpecah . Di satu sisi, ketika getaran molekul-molekul cukup kuat, mereka akan menguap bukan merengkah hal ini tentu saja tidak diharapkan. Rantai karbon baru akan pecah/merengkah jika energi yang dipengaruhi oleh gaya van der Waals terhadap rantai polimer lebih besar dari entalpi ikatan dalam rantai C-C. Ini alasan mengapa polimer dengan berat molekul yang besar akan terurai . Distribusi produk hasil pirolisis plastik dan biomassa pada variasi suhu telah dilakukan oleh beberapa peneliti guna menemukan suhu optimum terbentuknya biofuel. Dilaporkan bahwa, temperatur perengkahan polimer plastik berkisar pada suhu $350-425^{\circ} \mathrm{C}[28,54,55]$ sedangkan temperatur dekomposisi selulosa pada kisaran suhu $400-550^{\circ} \mathrm{C}$. Pada temperatur kurang dari $450^{\circ} \mathrm{C}$, jumlah padatan, bio-char, yang dihasilkan meningkat hal ini karena rendahnya konversi karbon dan rendahnya laju devolatilisasi $[23,46]$.

\subsection{Jenis Reaktor}

Reaktor adalah jantung dari berlangsungnya sebuah reaksi, dalam hal ini proses pirolisis. Jenis reaktor yang digunakan telah menjadi subyek penelitian yang serius, inovasi dan pengembangan dilakukan untuk meningkatkan karakteristik produk dan efisiensi proses seperti suhu yang tidak terlalu tinggi dan residence time yang singkat. Seiring dengan perkembangan teknologi pirolisis maka desain reaktor untuk maksud tersebut juga ikut berkembang guna optimalisasi performa proses pirolisis dan bertujuan untuk mengasilkan produk biofuel dengan yield yang tinggi dan berkualitas. Pada beberapa penelitian yang telah dilakukan, pirolisis dalam skala laboratorium, umumnya menggunakan reaktor batch, semibatch atau kontinyu (jenis fluidized bed dan fixed-bed) [12, 18, 20, 56, 57]. Masing-masing jenis reaktor ini memiliki keunggulan dan kelemahan yang akan dijelaskan berikut ini:

Reaktor batch adalah reaktor dengan sistem tertutup dimana tidak ada aliran reaktan masuk atau aliran produk keluar selama reaksi berlangsung [58]. Berbeda dengan batch, reaktor semi batch memungkinkan terjadi penambahan reaktan atau produk selama reaksi berlangsung. Salah satu keunggulan reaktor batch dan semi-batch adalah dapat diperoleh konversi yang tinggi dengan menambah waktu reaksi [59]. Namun, kelemahan dari reaktor batch maupun semi-batch terkait dengan variabilitas produk yang dihasilkan, biaya tenaga kerja tinggi dan tidak dapat diterapkan untuk skala yang besar [60]. Dilaporkan oleh beberapa peneliti bahwa reaksi pirolisis plastik menggunakan reaktor batch yang berlangsung pada suhu $300-550^{\circ} \mathrm{C}$ untuk berbagai jenis plastik telah menghasilkan biofuel (cair, gas dan padat), sementara pirolisis biomassa berlangsung pada suhu $400-550^{\circ} \mathrm{C}$ sebagaimana disajikan pada Tabel 2. 
Tabel 2. Produk Pirolisis dengan reaktor yang berbeda untuk berbagai Feedstock

\begin{tabular}{lcccc}
\hline \multirow{2}{*}{ Feedstock } & \multicolumn{3}{c}{ \% berat bahan bakar cair } & \\
\cline { 2 - 4 } & $\begin{array}{c}\text { Batch } \\
\text { Reaktor }\end{array}$ & $\begin{array}{c}\text { Fixed Bed } \\
\text { Reaktor }\end{array}$ & $\begin{array}{c}\text { Fluidized } \\
\text { Bed } \\
\text { Reaktor }\end{array}$ & $\begin{array}{c}\text { Referensi } \\
(\mathbf{T}=\mathbf{3 0 0}-\mathbf{5 5 0} \mathbf{C})\end{array}$ \\
\hline PET & - & 41,3 & & {$[18]$} \\
HDPE & - & 79,72 & 68.7 & {$[18]$} \\
& 67 & - & - & {$[57]$} \\
LDPE & 69,3 & 85 & - & {$[12]$} \\
& 74 & - & - & {$[39]$} \\
Tongkol Jagung & - & 84,25 & - & {$[18]$} \\
Biji Kapas & 80,1 & 87 & 80 & {$[12]$} \\
Jerami & 85 & - & - & {$[39]$} \\
Biji Sirsak & - & 47,3 & - & {$[48]$} \\
Serbuk gergaji & 43,6 & - & - & {$[48]$} \\
Kulit kacang mete & 18,6 & 33,5 & - & {$[48]$} \\
Bagase & - & - & - & {$[48]$} \\
Tandan kosong & 40 & 31,1 & - & {$[48]$} \\
sawit & - & - & - & {$[48]$} \\
\hline
\end{tabular}

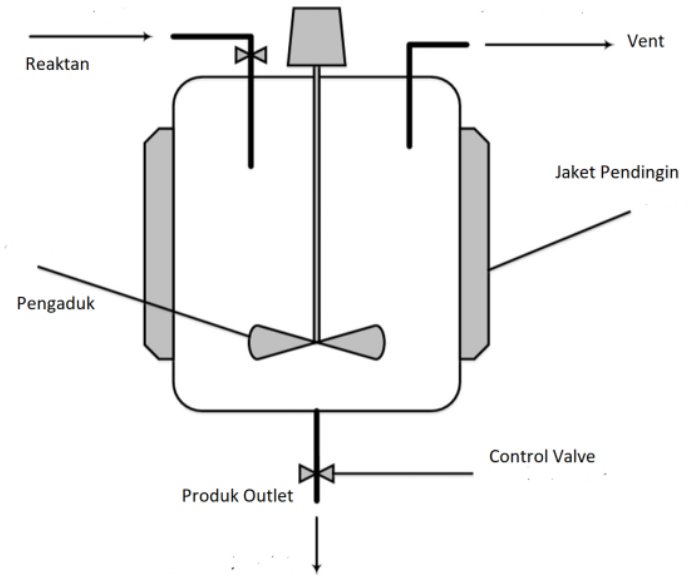

Gambar 1.a Konfigurasi Reaktor Batch

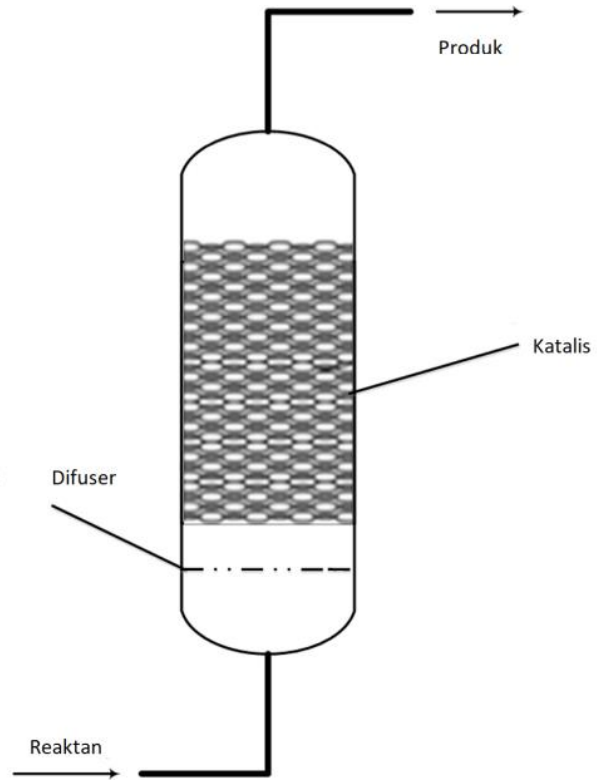

Gambar 1.b Konfigurasi Reaktor Fixed-Bed

Reaktor fixed-bed adalah sebuah reaktor berbentuk tabung silinder yang dipenuhi dengan katalis padat dimana reaktan mengalir melalui tumpukan katalis (biasanya berupa pellet) dan dikonversikan menjadi produk [59]. Konfigurasi reaktor fixed-bed seperti ditampilkan dalam Gambar 1.a [12]. Jenis reaktor ini memiliki kelemahan selama proses pengumpanan reaktan baik untuk pirolisis plastik [60] maupun untuk pirolisis biomassa [56]. Selain itu, luas permukaan katalis dimana kontak antar reaktan terjadi juga terbatas. Kelemahan dari reaktor fixed-bed kemudian diperbaiki dengan menggunakan reaktor fluidized-bed. Pada reaktor 
jenis ini, katalis diletakkan di atas piringan dimana fluidizing gas mengalir melalui partikel katalis yang kemudian bergerak seperti fluida namun tidak sampai meninggalkan reaktor seperti terlihat pada Gambar 1.b [56]. Hasil beberapa penelitian proses pirolisis plastik dan biomassa menggunakan reaktor fixed-bed dan reaktor fluidized bed disajikan pada Tabel 2. Di sini dapat dilihat bahwa hasil pirolisis untuk berbagai jenis bahan baku memberikan hasil terbaik dengan menggunakan fluidized bed reactor kecuali untuk bahan baku dari jerami menunjukkan hasil terbaik jika menggunakan batch reactor.

\subsection{Waktu Tinggal}

Waktu tinggal berbanding lurus dengan konversi sebuah reaksi. Konversi bahan baku, plastik atau biomassa, didefinisikan sebagai banyaknya massa bahan baku yang berubah menjadi produk terhadap massa mula-mula bahan baku dengan formula sebagai berikut: $\mathrm{x}=$ $\left[\mathrm{m}_{\mathrm{o}}-\mathrm{m}_{\mathrm{f}}\right] / \mathrm{m}_{\mathrm{o}}$ dengan $\mathrm{m}_{\mathrm{o}}=$ massa plastik saat awal, gram, $\mathrm{m}_{\mathrm{f}}=$ massa residu padat setiap saat, gram. Gambar 2 memperlihatkan pengaruh waktu tinggal terhadap konversi berbagai jenis plastik.

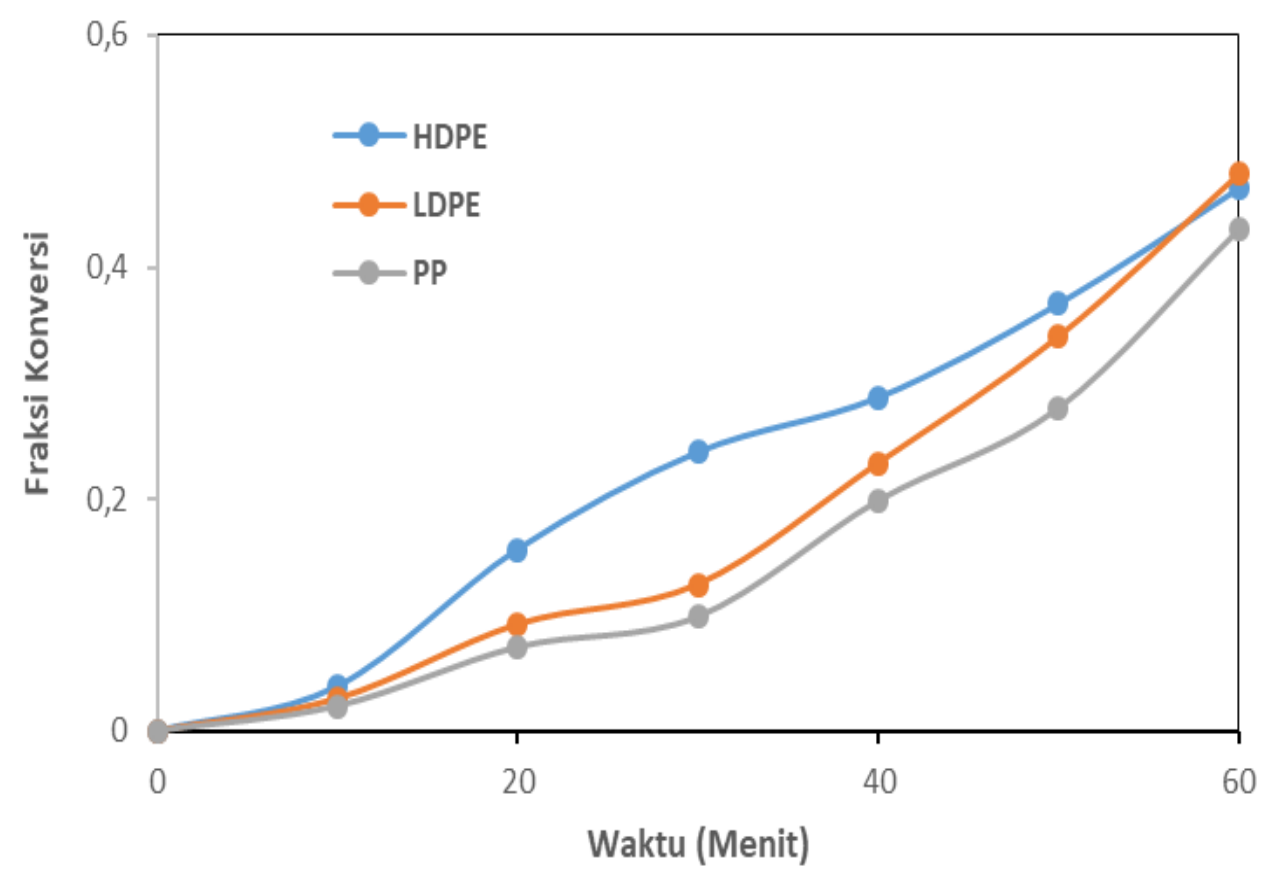

Gambar 2. Pengaruh waktu terhadap konversi pirolisis HDPE, LDPE, PP [61]

Dari gambar 2 dapat diamati kenaikan jumlah minyak yang dihasilkan setiap rentang waktu 0 menit. Hasil yang diperoleh sangat bergantung secara signifikan pada kenaikan suhu. Kenaikan suhu berbanding langsung dengan jumlah minyak yang dihasilkan, begitu juga dengan waktu reaksi yang semakin lama maka minyak yang dihasilkan akan semakin banyak. Dalam penelitian ini dilakukan percobaan secara duplo kemudian diambil nilai ratarata sehingga diperoleh hasil yang akurat. Jenis plastik LDPE memberikan hasil terbaik yaitu konversi pirolisis $48 \%$ pada waktu ke 60 menit [61]. 


\section{Kesimpulan}

Tulisan ini telah memberikan ringkasan singkat tentang pirolisis plastik dan biomassa untuk berbagai jenis dan fokus diskusi adalah menjelaskan pengaruh jenis feedstock, temperature, reaktor dan waktu reaksi untuk mengoptimalkan hasil bahan bakar minyak dimana kondisi terbaik diperoleh pada rentang temperatur $400-550^{\circ} \mathrm{C}$. Berdasarkan studi literatur ini, proses pirolisis disukai oleh kebanyakan peneliti karena memiliki potensi untuk mengkonversi limbah plastik dan biomassa menjadi bahan bakar minyak, gas dan char. Pirolisis dapat dilakukan dalam reactor batch maupun kontinyu dengan atau tanpa katalis. Dengan metode pirolisis, pengelolaan limbah menjadi lebih efisien, kapasitas TPA yang diperlukan menjadi berkurang, mengurangi polusi dan juga biaya menjadi lebih ekonomis.

\section{Ucapan Terima Kasih}

Dengan tulus diucapkankan terima kasih atas dukungan dana yang diberikan oleh Fakultas Teknologi Industri Universitas Jayabaya melalui dana penelitian dengan Nomor Kontrak: 71. 01/DEK/FTI-UJ /XII/2018 sehingga tulisan ini dapat diselesaikan.

\section{DAFTAR PUSTAKA}

[1] B. R. Singh and O. Singh, "Global Trends of Fossil Fuel Reserves and Climate Change in the 21st Century," Fossil Fuel and the Environment, pp. 167-192, 2012.

[2] M. M. Alla, A. Ahmed and B. K. Abdalla, "Conversion of Plastic Waste to Liquid Fuel," International Journal of Technical Research and Applications, vol. 2, no. 3, pp. 29-31, 2014.

[3] D. Almeida and M. d. F. Marques, "Thermal and catalytic pyrolysis of plastic waste," Polímeros, vol. 26, no. 1, pp. 44-51, 2016.

[4] I. Kholiq, "Pemanfaatan Energi Alternatif Sebagai Energi Terbarukan Untuk Mendukung Subtitusi BBM," Jurnal IPTEK, vol. 19, no. 2, pp. 76-91, 2015.

[5] Arhamsyah, "Pemanfaatan Biomassa Kayu Sebagai Sumber Energi Terbarukan," Jurnal Riset Industri Hasil Hutan, vol. 2, no. 1, pp. 42-48, 2010.

[6] D. Anisah, Herliati and A. Widyaningrum, "Pemanfaatan Sampah Sayuran Sebagai Bahan Baku Pembuatan Bioetanol," Jurnal Konversi, vol. 3, no. 1, pp. 13-17, 2014.

[7] E. K, M. G, A. Nego and F. X. A. Sugiyana, "Pengolahan Sampah Plastik dengan Metoda Pirolisis menjadi Bahan Bakar Minyak," in Seminar Nasional Teknik Kimia “Kejuangan”, Yogyakarta, 2016.

[8] P. A. Brownsort, "Biomass Pyrolysis Processes:Performance Parameters And Their Influence On Biochar System Benefits," University of Edinburgh, 2009. 
[9] R. Arun Joshi and R. Punia, "Conversion of Plastic Wastes Into Liquid Fuels," Recent Advances in Bioenergy Research, vol. 3, no. 1, pp. 444-454, 2014.

[10] A. R. P. Ali and Munawar, "Pengolahan Sampah Plastik Menjadi mInyak Menggunakan Proses Pirolisis," Jurnal Ilmiah Teknik Lingkungan, vol. 4, no. 1, pp. 44-53, 2010.

[11] K. K. B. Kemaritiman, "Hot Spot Sampah Laut Indonesia," World Bank Group, Jakarta, 2018.

[12] S. D. A. Sharuddin, F. Abnisa, W. M. A. W. Daud and M. K. Aroua, "A review on pyrolysis of plastic wastes," Energy Conversion and Management, vol. 115, no. 1, p. 308-326, 2016.

[13] F. Gao, Pyrolysis of Waste Plastics into Fuels, University of Canterbury, 2010.

[14] M. M. Gaurav, A. K.N. and S. Lingegowda, "Conversion Of LDPE Plastic Waste Into Liquid Fuel By Thermal Degradation," International Journal of Mechanical And Production Engineering, vol. 2, no. 4, pp. 104-107, 2014.

[15] V. B, Chanashetty and B. Patil, "Fuel from Plastic Waste," International Journal on Emerging Technologies(Special Issue on NCRIET-2015), vol. 6, no. 2, pp. 21-128, 2015.

[16] M. Sarker, M. M. Rashid and M. Molla, "Waste Plastic Conversion into Chemical Product Like Naphtha," Journal of Fundamentals of Renewable Energy and Applications, vol. 1, pp. 1-7, 2011.

[17] A. Machiraju, Harinath and K. Charan, "Extraction Liquid Hydrocarbon Fuel From Waste Plastic," in National Conference On Trends In Science, Engineering \& Technology by Matrusri Engineering College, India, 2018.

[18] G. J. Ghewade, J. S. Bagi, S. B. Desai and M. M. Wagh, "A Review on Liquid Fuel Recovery from Waste Plastic Using Pyrolysis Process," International Journal for Research in Applied Science \& Engineering Technology, vol. 5, no. 9, pp. 375-379, 2017.

[19] R. Miandad, M. Barakat, M. Rehan, A. Aburiazaiza, I. Ismail and A. Nizami, "Plastic waste to liquid oil through catalytic pyrolysis using natural and synthetic zeolite catalysts," Waste Management, 2017.

[20] M. I. Jahirul, M. G. Rasul, A. A. Chowdhury and N. Ashwath, "Biofuels Production through Biomass Pyrolysis," Energies , vol. 5, no. 1, pp. 4952-5001, 2012.

[21] A. Mishra, "Renewable Energy Production from Lantana Camara Biomass," Global Journal of Human-Social Science: Interdisciplinary, vol. 18, no. 3, 2018. 
Jurnal Teknologi, Tahun 2019, Volume 6, Edisi 2

[22] T.Iskandar and N. Siswanti, "Pemanfaatan Limbah Pertanian Sebagai Energi Alternatif Melalui Konversi Thermal," Buana Sains , vol. 12, no. 1, pp. 117-122, 2012.

[23] M. Rasul and M. Jahirul, "Recent Developments in Biomass Pyrolysis for Bio-Fuel Production: Its Potential for Commercial Applications," Recent Researches in Environmental and Geological Sciences, pp. 256-265, 2010.

[24] J. T. Oladeji, E. Itabiyi and P. O. Okekunle, "A Comprehensive Review of Biomass Pyrolysis as a Process of Renewable Energy Generation," Journal of Natural Sciences Research, vol. 5, no. 5, pp. 99-105, 2015.

[25] H. Sharma, "Innovative and Sustainable Application of PET Bottle a Green Construction Overview," Indian Journal of Science and Technology, vol. 10, no. 16, pp. 1-6, 2017.

[26] "Emission Factors," in Organic Chemical Process Industry, pp. 6.6.2-1-6.6,2-13.

[27] M. Sulyman, K. Formela and J. T. Haponiuk, "Utilization of Recycled Polyethylene Terephthalate (PET) in Engineering Materials: A Review," International Journal of Environmental Science and Development, vol. 7, no. 2, pp. 100-108, 2016.

[28] Rajaram.T.Karad and S. Havalammanavar, "Waste plastic to fuel-Petrol, Diesel, Kerosene," International Journal of Engineering Development and Research, vol. 5, no. 3, pp. 641-645, 2017.

[29] S. V. Papuga, P. M. Gvero and L. M. Vukic, "Temperature And Time Influence On The Waste Plastics Pyrolisis In The Fixed Bed Reactor," Thermal Science, vol. 20, no. 2, pp. 731-741, 2016.

[30] G.-G. Choi, S.-J. Oh and J.-S. Kim, "Intermediate pyrolysis of scrap tires in a fixed bed reactor and activation of the pyrolysis char using $\mathrm{CO} 2$ : Characteristics of pyrolysis products and activated char," in 7th International Symposium on Feedstock Recycling of Polymeric Materials, New Delhi, 2013.

[31] K. T. Kyaw and C. S. S. Hmwe, "Effect of Various Catalysts on Fuel Oil Pyrolisis of Mixed Plastic Wastes," International Journal of Advances in Engineering \& Technology, vol. 8, no. 5, pp. 794-802, 2015.

[32] D. Y. Hopa, A. Yilmaz and T. A. Bahtli, "Recovery of waste tyres by pyrolysis in a fixed bed reactor for liquid fuel production: effects of pyrolysis conditions on oil yield," Engieering Structures and Materials, vol. 3, no. 3, pp. 186-191 , 2017.

[33] A. Vijayakumar and J. Sebastian, "Pyrolysis process to produce fuel from different types of plastic - a review," Materials Science and Engineering, pp. 1-8, 2018.

[34] N. L. Rahim, S. Salehuddin, N. M. Ibrahim1, R. C. Amat and M. F. A. Jalil, "Use of 
Jurnal Teknologi, Tahun 2019, Volume 6, Edisi 2

Plastic Waste (High Density Polyethylene) In Concrete Mixture as Aggregate Replacement," Advance Material Research, vol. 70, no. 1, pp. 265-269, 2013.

[35] Orkustofnun, "Pyrolysis of plastic waste for fuel production," Resource International EHF, Northern Europe, 2015.

[36] M. A. Goad and R. Ali, "Thermal and Catalytic Cracking of Plastic Wastes into Hydrocarbon Fuels," International Journal of Engineering and Information Systems (IJEAIS), vol. 1, no. 5, pp. 56-61, 2017.

[37] A. Olufemi and S. Olagboye, "Thermal conversion of waste plastics into fuel oil," International Journal of Petrochemical Science \& Engineering, vol. 2, no. 8, p. 252-257, 2017.

[38] H. A. Gabbar, M. Aboughaly and C. B. Stoute, "DC Thermal Plasma Design and Utilization for the Low Density Polyethylene to Diesel Oil Pyrolysis Reaction," Energies, vol. 10, no. 6, pp. 1-15, 2017.

[39] M. S. Abbas-Abadi, A. G. McDonald, M. N. Haghighi and H. Yeganeh, "Estimation of pyrolysis product of LDPE degradation using different process parameters in a stirred reactor," Polyolefins Journal, vol. 2, no. 1, pp. 39-47, 2015.

[40] H. A. Maddah, "Polypropylene as a Promising Plastic: A Review," American Journal of Polymer Science, vol. 6, no. 1, pp. 1-11, 2016.

[41] C. Areeprasert, J. Asingsamanunt, S. Srisawat, J. Kaharn, B. Inseemeesak, P. Phasee, C. Khaobang, W. Siwakosit and C. Chiemchaisri, "Municipal Plastic Waste Composition Study at Transfer Station of Bangkok and Possibility of its Energy Recovery by Pyrolysis," in 3rd International Conference on Energy and Environment Research, ICEER, Spain, 2016.

[42] M. B. Kutoli, K. S. Shegunsi, Imagoudanavar, M. A and A. S. Malaji, "Production and Purification of Liquid Fuel From Houehold Plastik Waste For CI Engine," Visvesvaraya Technological University, India, 2016.

[43] W. Hermann, P. Bosshard, E. H. Hunt and A. Simon, "An Assessment of Biomass Feedstock and Conversion Research Opportunities," GCEP , California, 2005.

[44] H. Cser and L. Boby, "Biomass Feedstocks Characteristics," USDA National Institute of Food and Agriculture, United State, 2015.

[45] J. Bates, "Biomass Feedstock Availability," Ricardo Energy \& Environment reference:, United Kingdom, 2017.

[46] K. Parmar, "Biomass- An Overview on Composition Characteristics and Properties," 
IRA-International Journal of Applied Sciences, vol. 7, no. 1, pp. 42-51, 2017.

[47] L. Liua, X. P. Yea, A. R. W. and S. Sokhansanj, "Variability of biomass chemical composition and rapid analysis using FT-NIR techniques," Carbohydrate Polymers, vol. 81, no. 1, p. 820-829, 2010.

[48] A. Verma, R. Shankar and P. Mondal, A Review on Pyrolysis of Biomass and the Impacts of Operating Conditions on Product Yield, Quality, and Upgradation, India: Springer, 2018.

[49] S. B. A. H. H. V. Lee and S. K. Zain, "Conversion of Lignocellulosic Biomass to Nanocellulose: Structure and Chemical Process," Scientific World Journal, pp. 1-20, 2014.

[50] M. A. Wicaksono and Arijanto, "Pengolahan Sampah Plastik Jenis PET(Polyethylene Perepthalathe) Menggunakan Metode Pirolisis Menjadi Bahan Bakar Alternatif," Jurnal Teknik Mesin, vol. 5, no. 1, pp. 9-15, 2017.

[51] C. Santaweesuk and A. Janyalertadun, "The Production of Fuel Oil by Conventional Slow Pyrolysis Using Plastic Waste from a Municipal Landfill," International Journal of Environmental Science and Development, vol. 8, no. 3, pp. 168-173, 2017.

[52] R. Rafli, M. Syamsiro and H. B. Fajri, "Penerapan Teknologi Pirolisis Untuk Konversi Limbah Plastik Menjadi Bahan Bakar Minyak di Kabupaten Bantul," Jurnal Teknologi, vol. 2, no. 1, pp. 1-5, 2017.

[53] S. D. A. Sharuddin, F. Abnisa, W. M. A. W. Daud and M. KAroua, "Pyrolysis of plastic waste for liquid fuel production as prospective energy resource," IOP Conf. Series: Materials Science and Engineering, vol. 334, no. 1, pp. 1-8, 2018.

[54] I. M. Idriss, M. M. Ahmed and A. S. Grema, "Effect of Temperature on Products Compositions of Beech Wood Pyrolysis," Faculty of Engineering Seminar Series, vol. 8, no. 1, pp. 25-30, 2017.

[55] Z. Tamri, A. V. Yazdi, M. N. Haghighi, M. Seifali, Abbas-Abad and A. Heidarinasab, "Effect of temperature, heating rate and zeolite-based catalysts on the pyrolysis of high impact polystyrene (HIPS) waste to produce fuel-like products," Polyolefins Journal, vol. 6, no. 1, pp. 43-52, 2019.

[56] P. Kaushal and J. Abedi, "A simplified model for biomass pyrolysis in a fluidized bed reactor," Journal of Industrial and Engineering Chemistry, vol. 16, no. 1, pp. 748-755, 2010.

[57] B. Fekhar, T. Bhaskar, N. Miskolczi and J. Kumar, "Co-pyrolysis of biomass and plastic wastes: investigation of apparent kinetic parameters and stability of pyrolysis oils," in 
Jurnal Teknologi, Tahun 2019, Volume 6, Edisi 2

7th International Conference on Clean and Green Energy-ICCGE, 2018.

[58] O. Levenspiel, Chemical Reaction Engineering, Toronto: John Wiley \& Sons , 1999.

[59] H. Fogler, Elements of Chemical Reaction Engineering, Edinburgh: Pearson, 2014.

[60] J. Kluska, M. Klein, P. Kazimierski and D. Kardas, "Pyrolysis of biomass and refusederived fuel performance in laboratory scale batch reactor," Szewalski Institute of FluidFlow Machinery, Poland, 2014.

[61] Herliati, S. B. Prasetyo and Y. Verinaldi, "Pemanfaatan Limbah Plastik Sebagai Bahan Baku Pembuatan Kerosen," Fakultas Teknologi Industri Universitas Jayabaya, Jakarta, 2019. 